\title{
PENERAPAN BAHAN AJAR FISIKA DENGAN VARIASI BENTUK TUGAS BERBASIS WEB UNTUK MENINGKATKAN HASIL BELAJAR MAHASISWA TEKNIK
}

\author{
Eliyarti ${ }^{1}$, Chichi Rahayu ${ }^{1}$, Zakirman ${ }^{2}$ \\ (1)Universitas Ekasakti Padang, Padang, Indonesia \\ (2)Universitas Negeri Padang, Padang, Indonesia \\ rahayuchichi@gmail.com
}

\begin{abstract}
Abstrak
Pembelajaran menggunakan bahan ajar berbasis web menjadi salah satu media berbasis teknologi yang dapat diterapkan dalam pembelajaran Fisika. Dengan menerapkan pembelajaran menggunakan bahan ajar berbasis web di perguruan tinggi, khususnya dalam perkuliahan Fisika, diharapkan mahasiswa mampu memahami berbagai konsep Fisika dan soal-soal menggunakan teknologi. Tujuan penelitian ini untuk menyelidiki pengaruh penerapan bahan ajar Fisika dengan variasi tugas berbasis web terhadap hasil belajar mahasiswa. Jenis penelitian yang digunakan adalah penelitian eksperimen semu didasarkan atas adanya kelas eksperimen dan kelas kontrol dengan Randomized Control Group Only Design. Populasi penelitian ini mahasiswa tingkat I Fakultas Teknik dan Perencanaan Universitas Ekasakti dalam perkuliahan Fisika Dasar semester ganjil 2019/2020. Instrumen penelitian menggunakan tes tertulis yang terdiri dari soal objektif. Teknik analisis data menggunakan uji-t, namun sebelumnya dilakukan uji normalitas dan uji homogenitas. Berdasarkan penelitian diperoleh nilai rata-rata hasil belajar Fisika mahasiswa kelas eksperimen adalah 84,75 sedangkan kelas kontrol 80,69. Hal ini menunjukan hasil belajar Fisika mahasiswa kelas eksperimen lebih tinggi dari nilai rata-rata hasil belajar Fisika kelas kontrol. Kemudian dilakukan uji-t terhadap hasil belajar tersebut diperoleh bahwa thitung $>t_{\text {tabel, }}$ yaitu 2,04 $>1,67$. Ini bearti terdapat perbedaan yang signifikan pada hasil belajar menggunakan bahan ajar berbasis web dibandingkan hasil belajar yang tidak menggunakan bahan ajar ini. Dengan demikian penerapan bahan ajar Fisika dengan variasi bentuk tugas berbasis web memberikan pengaruh berupa peningkatan nilai rata-rata terhadap hasil belajar mahasiswa teknik.
\end{abstract}

Kata kunci: bahan ajar Fisika; pembelajaran berbasis web; variasi tugas;

\begin{abstract}
Learning used web-based teaching materials was one of the technology-based media that can be applied in learning physics. By implemented learning using web-based teaching materials in universities, especially in Physics lectures, students are expected to be able to understand various physics concepts and problems used technology. The purpose of this study was to determine the effect of the application of web-based teaching materials on student learning outcomes. This type of research was quasi-experimental research based on the existence of an experimental class and a control class with a randomized control group only design. The population of this research was students of level I Faculty of Engineering and Planning, Ekasakti University in Basic Physics lecture odd semester 2019/2020. The research instrument used a written test consisting of objective questions. The data analysis technique used the t-test which was previously tested for normality and homogeneity test. Based on the research, it was found that the average value of learning outcomes for students in the experimental class was 84.75 while the control class was 80.69 . This shows that the physics learning outcomes of the experimental class students were higher than the average value of the control class physics learning outcomes. Then the t-test was carried out on the learning outcomes, it was found that $t_{\text {count }}>t_{\text {table }}$, which was $2.04>1.67$. This means, there is a significant difference in learning outcomes using web-based teaching materials compared to learning outcomes which do not use this teaching material. It can be cocluded that the application of web-based teaching materials with various assignment influences the increase in the average value of the learning outcomes of engineering students.
\end{abstract}

Keywords : Physics teaching materials; web-based learning; the variety of tasks;

\section{Pendahuluan}

Bidang pendidikan memegang peranan penting dan strategis sebab merupakan sebuah wahana untuk meningkatkan kualitas sumber daya manusia (Zakirman \& Rahayu, 
2018). Tujuan utama pendidikan adalah untuk membuat perubahan dan mendidik manusia untuk meningkatkan kualitas hidup (Zakirman, Lufri, Khairani, \& Rahayu, 2020a). Tuntutan pendidikan yang sangat besar mendorong para pendidik dan mahasiswa untuk dapat berpartisipasi dalam berbagai perkembangan di dunia pendidikan (Putri, Ulhusna, Zakirman, \& Gusta, 2020). Oleh karena itu, peningkatan kualitas pendidikan merupakan suatu keharusan bagi kemajuan bangsa, begitu pula dengan bangsa Indonesia (Zakirman, Lufri, \& Khairani, 2018)

Kualitas pendidikan dapat dibentuk oleh kualitas pembelajaran (Zakirman, 2019). Meningkatkan kualitas pembelajaran penting untuk dilakukan mulai dari pendidikan dasar dan menengah hingga pendidikan tinggi (Gusta, Christina, \& Zakirman, 2020). Kegiatan pembelajaran di perguruan tinggi melibatkan mahasiswa secara aktif untuk berinteraksi. Dosen harus mampu melaksanakan pembelajaran dengan berorientasi pada kegiatan mahasiswa dalam menemukan dan menetapkan makna secara mandiri sehingga proses pembelajaran akan dapat mengembangkan keterampilan berpikir tinggi (Rahayu \& Eliyarti, 2019). Oleh karena itu, pengunaan sumber belajar diperlukan untuk menunjang kegiatan pembelajaran. Salah satu sumber belajar yang penting dalam kegiatan pembelajaran adalah bahan ajar.

Bahan ajar merupakan seperangkat materi yang disusun secara sistematis tertulis baik maupun tidak sehingga tercipta lingkungan suasana yang memungkinkan mahasiswa untuk belajar (Daryanto, 2014). Bahan ajar merupakan segala bentuk bahan yang berisi materi pembelajaran untuk digunakan dalam proses pembelajaran dimana materi pembelajaran tersebut hendaknya dapat dipelajari dan dikuasai mahasiswa, baik berupa pengetahuan, keterampilan, maupun sikap melalui kegiatan pembelajaran (Setiawan \& B, 2017). Bahan ajar diperguruan tinggi dapat berupa cetak maupun non cetak. Bahan ajar cetak meliputi buku teks, modul, lembar kerja dan lain-lain, sedangkan non cetak menggunakan video dan e-learning. Bahan ajar ini memuat materi dan tugas-tugas untuk mahasiswa. Banyaknya jenis bahan ajar tersebut berbanding lurus dengan semakin berkembangnya teknologi. Perkembangan ini juga bermanfaat terhadap pembelajaran, salah satunya memudahkan dosen untuk memberikan variasi dalam kegiatan pembelajaran.

Variasi dalam kegiatan pembelajaran penting untuk dilakukan. Variasi adalah keanekaan yang membuat sesuatu tidak monoton (Uzer, 2008). Dalam konteks proses interaksi belajar mengajar variasi ditujukan untuk mengatasi kebosanan mahasiswa. Dengan adanya variasi diharapkan mahasiswa senantiasa menunjukkan ketekunan, antusiasme serta penuh partisipasi. Dalam pemberian tugas, variasi bentuk tugas sebagai suatu kegiatan dalam konteks proses interaksi belajar mengajar dengan memberikan berbagai bentuk tugas-tugas yang ditujukan untuk meningkatkan keaktifan mahasiswa. Tugas merupakan suatu pekerjaan yang harus diselesaikan oleh mahasiswa. Tugas dapat dikerjakan secara individu, secara kelompok, maupun untuk seluruh kelas, tugas dapat dikerjakan di dalam kelas, di luar kelas atau diluar jam pelajaran sebagai pekerjaan rumah (Sudjana, 2011). Melalui pemberian tugas, mahasiswa akan memiliki keinginan dan tuntutan untuk melakukan aktifitas belajar, yaitu kebutuhan untuk menyelesaikan tugas yang diberikan (Bhakti, 2017).

Metode pemberian tugas merupakan suatu metode cara mengajar yang dilakukan oleh dosen dengan memberikan tugas-tugas pada mahasiswa mengenai suatu pokok bahasan. Tugas ini dapat dilakukan secara individu dan kelompok dan harus diselesaikan dalam waktu yang telah ditentukan (Yulizon, 2017). Pemberian tugas yang baik dapat membantu mahasiswa mencapai kompetensi. Metode pemberian tugas efektif digunakan karena: 1) lebih menstimulus mahasiswa dalam melakukan aktifitas belajar individual ataupun kelompok; 2) dapat mengembangkan kemandirian mahasiswa diluar pengawasan dosen; 3) dapat membina tanggung jawab dan disiplin mahasiswa; dan 4) dapat mengembangkan kreativitas mahasiswa (Prihatini, 2018).

Tugas yang diberikan kepada mahasiswa hendaknya mempertimbangkan beberapa hal, di antaranya: tujuan yang akan dicapai, jenis tugas jelas dan tepat, sesuai dengan kemampuan mahasiswa, ada petunjuk/sumber yang dapat membantu mahasiswa, waktu yang cukup untuk mengerjakan tugas tersebut (Sudjana, 2011). Dengan demikian, 
pemberian tugas yang baik akan memperhatikan hal-hal tersebut sehingga pemberian tugas tidak serampangan. Adanya tujuan yang akan dicapai dan jenis tugas yang jelas dapat menghindarkan kekeliruan dalam pengerjaan tugas. Tugas yang diberikan haruslah sesuai dengan kemampuan mahasiswa, karena tugas dimaksudkan untuk melatih mahasiswa agar tujuan kompetensi tercapai.

Kegiatan pembelajaran berkaitan dengan bagaimana meningkatkan rasa ingin tahu mahasiswa. Cara untuk mengembangkan rasa ingin tahu mahasiswa dapat dirancang melalui pengajaran yang berorientasi pada proses (Zakirman, Lufri, Khairani, \& Rahayu, 2020b). Untuk mengembangkan rasa ingin tahu mahaiswa dapat melalui kegiatan menyelesaikan soal-soal. Semakin sering berlatih soal maka rasa ingin tahu mahasiswa juga semakin meningkat. Dengan demikian mahasiswa akan terlatih untuk belajar serta memiliki konsekuensi penting untuk apa mereka memperhatikan, bagaimana mereka memproses informasi, dan bagaimana mereka bereaksi terhadap kuliah (Eliyarti \& Rahayu, 2019a).

Penggunaan teknologi e-learning berbasis web dapat memperkaya pengalaman belajar dengan dimensi baru, yaitu (1) multimediality; belajar lebih mudah karena membantu mahasiswa untuk fokus dan menjaga perhatian mereka pada isi yang kompleks, beraktivitas dengan indera yang berbeda; (2) hypertextuality; terstruktur sebagai sebuah sistem manifold hubungan on-linear antara teks, yang memungkinkan mahasiswa untuk mengikuti jalan mereka sendiri dan untuk membuat yang baru; (3) interaktivitas; memungkinkan untuk bekerja dengan materi dalam pendekatan belajar melalui kerja dengan keterlibatan yang lebih tinggi, pemahaman yang dalam, dan retensi yang lebih baik dari subjek (Tambunan, 2013). Dengan melihat manfaat-manfaat ini maka penggunaan teknologi juga penting dalam kegiatan pembelajaran.

Teknologi e-learning yang digunakan dalam penelitian ini adalah moodle. Moodle merupakan sebuah Open Source Course Management System (CMC), yang berarti tempat belajar dinamis dengan menggunakan model berorientasi objek, juga dikenal sebagai Learning Management System (LMS) atau Virtual Learning Environment (VLE). Moodle merupakan sebuah program aplikasi yang dapat merubah media pembelajaran ke dalam bentuk web. Manfaat dari pengunaan LMS menggunakan Moodle secara online sangat penting, diantaranya adalah mengatasi keterbatasan frekuensi tatap muka antara mahasiswa dengan dosen. Moodle dalam pembelajaran sains banyak digunakan sebagai salah satu media pembelajaran karena membantu dalam mengajar sains (Herayanti, Fuadunnazmi, \& Habibi, 2017). Beberapa alasan menggunakan moodle untuk meningkatkan pengajaran, yaitu: (1) mampu memberikan mahasiswa akses ke materi kuliah dalam lingkungan yang terkendali sehingga pembelajaran dapat berlangsung dimana saja; (2) memantau kemajuan dan menyimpan catatan belajar mahasiswa; (3) memperluas kelas dengan menyediakan diskusi online, evaluasi, kegiatan, dan yang paling penting memungkinkan kolaborasi serta komunikasi untuk pembelajaran; (4) memanfaatkan multimedia yang menarik, media 3D interaktif, dan konten berbasis web yang memungkinkan mahasiswa dengan gaya belajar yang berbeda untuk mengakses kurikulum; dan (5) membantu pendidik sains berkolaborasi, berbagi, dan menyimpan sumber daya pengajaran (Hartanto \& Purbo, 2005).

Penelitian terdahulu yang dilakukan oleh Hidayatulah, Yushardi dan Wahyuni (2013) menunjukan bahan ajar berbasis web interaktif dengan aplikasi e-learning moodle dapat meningkatan hasil belajar mahasiswa dalam kategori sedang dimana peningkatan rata-rata hasil belajar mahasiswa sebesar 0,42 (Hidayatulah, Yushardi, \& Wahyuni, 2013). Selanjutnya Purmadi dan Surjono (2016) melakukan penelitian yang menunjukan bahwa terjadi peningkatan pencapaian hasil belajar mahasiswa setelah menggunakan bahan ajar berbasis web sebesar 31,87\% (Purmadi \& Surjono, 2016). Penelitian yang dilakukan Martono (2017) menunjukan bahwa pemberian tugas berbasis multimedia berpengaruh terhadap hasil belajar mahasiswa (Martono, 2017). Penelitian-penelitian tersebut telah menunjukan adanya pengaruh positif penggunaan teknologi dalam kegiatan pembelajaran. 
Fisika merupakan bidang ilmu yang memberikan pengetahuan tentang alam semesta untuk berlatih berpikir dan bernalar. Semakin dilatih maka kemampuan penalaran akan semakin berkembang, sehingga daya pikir dan pengetahuan akan bertambah. Atas dasar inilah Fisika penting untuk diajarkan pada mahasiswa (Supardi, Leonard, Suhendri, \& Rismurdiyati, 2018). Pembelajaran Fisika diperguruan tinggi menuntut mahasiswa memahami berbagai teori, prinsip, dan konsep serta terdapat berbagai tugas untuk menyelesaikan berbagai soal-soal. Pembelajaran fisika dapat dikatakan baik apabila mahasiswa mampu menganalisis soal-soal yang diberikan dosen. Pemberian tugas bertujuan agar mahasiswa memiliki hasil belajar yang lebih mantap karena terbiasa mengerjakan latihan-latihan selama melakukan tugas, sehingga pengalaman mereka dalam mempelajari sesuatu dapat lebih terintegrasi (Martono, 2017).

Fisika Dasar merupakan salah satu mata kuliah wajib di FT Universitas Ekasakti. Matakuliah ini terdiri dari 3 sks dengan memuat banyak konsep dan soal-soal Fisika. Berdasarkan data hasil belajar semester 2018/2019, mahasiswa yang lulus mata kuliah ini kurang dari setengah jumlah mahasiswa yaitu hanya $42,17 \%$. Selain itu, 68,92\% mahasiswa menyatakan perkuliahan Fisika Dasar monoton dan tidak menarik. Untuk itu perlu dilakukan pemberian variasi bentuk tugas untuk menghadirkan pembelajaran yang menyenangkan. Didukung kemajuan teknologi pembelajaran berbasis web dengan variasi bentuk tugas diharapkan dapat menghilangkan kebosanan, meningkatkan minat dan keingintahuan mahasiswa, melayani gaya belajar mahasiswa yang beragam, dan meningkatkan kadar keaktifan mahasiswa. Dengan demikian dapat dituliskan bahwa tujuan dari penelitian ini menyelidiki pengaruh penerapan bahan ajar Fisika dengan variasi bentuk tugas berbasis web terhadap hasil belajar mahasiswa.

\section{Metode}

Jenis penelitian yang dilakukan adalah penelitian eksperimen semu. Penelitian ini didasarkan atas adanya kelas eksperimen dan kelas kontrol dengan Randomized Control Group Only Design. Mahasiswa yang berada pada kelas eksperimen diberi perlakuan berupa penggunaan bahan ajar dengan variasi bentuk tugas berbasis web, sedangkan mahasiswa pada kelas kontrol tidak menggunakan bahan ajar dengan variasi bentuk tugas berbasis web. Sesuai dengan jenis penelitian tersebut, maka rancangan penelitian yang digunakan dapat dilihat pada Tabel 1.

Tabel 1. Rancangan Penelitian

\begin{tabular}{lll} 
& Treatment & Posttest \\
\hline Exp. Group & $\mathrm{X}$ & $\mathrm{T}$ \\
\hline Control. Group & - & $\mathrm{T}$ \\
\hline
\end{tabular}

Keterangan:

$\mathrm{X}=$ Perlakuan berupa penggunaaan bahan ajar dengan variasi bentuk tugas berbasis web

- = Pembelajaran tanpa menggunakan bahan ajar dengan variasi bentuk tugas berbasis web

$\mathrm{T}$ = Tes akhir yang diberikan pada kelas eksperimen dan kelas kontrol setelah akhir pembelajaran.

Populasi dalam penelitian ini adalah mahasiswa tingkat I Fakultas Teknik dan Perencanaan Universitas Ekasakti dalam perkuliahan Fisika Dasar semester ganjil 2019/2020. Jenis data dalam penelitian ini adalah data primer yaitu data yang langsung diperoleh dari hasil perlakuan terhadap sampel penelitian. Perlakuan ini berupa pemberian bahan ajar Fisika dengan variasi bentuk tugas berbasis web. Data hasil belajar mahasiswa diambil setelah mahasiswa diberikan tes akhir.

Secara umum, prosedur penelitian dapat dibagi atas tiga tahap, yaitu persiapan, pelaksanaan, dan evaluasi. Pada tahap persiapan yang dilakukan adalah menentukan kelaskelas sampel, mempersiapkan perangkat pembelajaran yang disusun berdasarkan program tahunan dan program semester, mempersiapkan bahan ajar Fisika dengan variasi bentuk tugas berbasis web, mempersiapkan instrumen penelitian seperti soal-soal tes akhir. 
Selanjutnya pada tahap pelaksanaan kelas sampel eksperimen diberi perlakuan berupa bahan ajar dengan variasi bentuk tugas berbasis web dan kelas kontrol tidak diberi perlakuan tersebut. Kemudian pada tahap evaluasi dilakukan uji coba soal tes akhir yang telah disiapkan sebelumnya, menganalisis hasil uji coba soal, melakukan tes akhir untuk kedua kelas sampel. Instrumen penelitian menggunakan tes tertulis yang terdiri dari soal objektif.

Analisis data bertujuan untuk menguji apakah hipotesis kerja yang diajukan dalam penelitian ini diterima atau ditolak. Sebagai hipotesis kerja penelitian yaitu: terdapat pengaruh yang berarti penerapan bahan ajar Fisika dengan vaiasi tugas berbasis web terhadap hasil belajar mahasiswa teknik. Teknik analisis data menggunakan uji kesamaan dua rata-rata (uji-t) untuk menguji apakah diterima atau ditolaknya hipotesis penelitian, namun sebelum uji-t dilakukan uji normalitas dan uji homogenitas. Namun sebelum dilakukan uji hipotesis, terlebih dahulu dilakukan uji prasyarat beruapa uji normalitas dan homogenitas.

Untuk menguji hipotesis maka dilakukan uji kesamaan dua rata-rata (uji-t) dengan persamaan sebagai berikut:

Keterangan :

$$
\mathrm{t}=\frac{\overline{\mathrm{x}}_{1}-\overline{\mathrm{x}}_{2}}{\mathrm{~S} \sqrt{\frac{1}{\mathrm{n}_{1}}+\frac{1}{\mathrm{n}_{2}}}}
$$

$$
\begin{aligned}
& \overline{\mathrm{X}_{1}}=\text { Nilai rata-rata kelas eksperimen } \\
& \overline{\mathrm{X}_{2}}=\text { Nilai rata-rata kelas kontrol } \\
& \mathrm{S}=\text { Standar deviasi gabungan } \\
& \mathrm{n}_{1}=\text { Jumlah mahasiswa kelas eksperimen } \\
& \mathrm{n}_{2}=\text { Jumlah mahasiswa kelas kontrol }
\end{aligned}
$$

Harga $t_{\text {hitung }}$ dibandingkan dengan $t_{\text {tabel }}$ yang terdapat dalam tabel distribusi t. Kriteria pengujian adalah terima $H_{\circ}$ jika : $t_{\text {hitung }}<t_{\text {tabel }}$ pada taraf signifikan 0,05 untuk harga lainnya $\mathrm{H}_{\mathrm{o}}$ ditolak

\section{Hasil dan Pembahasan}

Data yang dideskripsikan dari penelitian ini adalah data hasil belajar Fisika mahasiswa dikelas eksperimen dan kelas kontrol. Hasil belajar mahasiswa di kelas sampel, baik kelas eksperimen maupun kelas kontrol diperoleh melalui pemberian tes akhir berupa soal objektif. Setelah melakukan analisis soal maka didapatkan soal yang layak dipakai dengan jumlah soal 35 butir sebagai soal tes akhir untuk kedua kelas sampel. Setelah pemberian tes akhir didapatkan data hasil belajar masing-masing mahasiswa pada kelas eksperimen yang berjumlah 24 orang dan kelas kontrol yang berjumlah 23 orang. Dari hasil perhitungan secara statistik, diperoleh nilai rata-rata $(\bar{x})$, simpangan baku $(S)$, dan varians $\left(S^{2}\right)$ kelas eksperimen dan kontrol seperti pada Tabel 2.

Tabel 2. Parameter Statistik Deskriptif Hasil Belajar

\begin{tabular}{lllll} 
Kelas & $\mathrm{N}$ & $\begin{array}{l}\text { Nilai } \\
\text { Terting } \\
\text { gi }\end{array}$ & $\begin{array}{l}\text { Nilai } \\
\text { Terend } \\
\text { ah }\end{array}$ & $\bar{X}$ \\
\hline Eksperimen & 24 & 97 & 74 & 84,75 \\
\hline Kontrol & 23 & 91 & 71 & 80,69 \\
\hline
\end{tabular}

Pada tabel 2 terlihat bahwa nilai rata-rata hasil belajar Fisika mahasiswa kelas eksperimen lebih tinggi dari nilai rata-rata hasil belajar Fisika kelas kontrol. Selanjutnya dilakukan analisis data yang bertujuan untuk menguji apakah diterima atau ditolaknya hipotesis yang telah diajukan dalam penelitian. Uji hipotesis ini merupakan uji kesamaan dua rata-rata dari kedua kelas sampel yang sebelumnya dilakukan uji normalitas dan uji homogenitas. 
Untuk melihat apakah kelas sampel berasal dari populasi yang terdistribusi normal atau tidak, maka dilakukan uji normalitas menggunakan uji Lilliefors terhadap tes hasil belajar pada kedua kelas sampel. Setelah dilakukan perhitungan pada kedua kelas sampel diperoleh hasil seperti disajikan pada Tabel 3.

Tabel 3. Hasil Perhitungan Uji Normalitas Kelas Eksperimen dan Kontrol Setelah Kegiatan

\begin{tabular}{llllll}
\multicolumn{6}{c}{ Pembelajaran } \\
\hline Kelas & $\mathrm{N}$ & $\alpha$ & $\mathrm{L}_{0}$ & $\mathrm{~L}_{\mathrm{t}}$ & Ket \\
\hline Eksperimen & 24 & 0,05 & 0,1064 & 0,1764 & Normal \\
& & & & & \\
\hline Kontrol & 23 & 0,05 & 0,1001 & 0,1798 & Normal \\
\hline
\end{tabular}

Pada Tabel 3 menunjukkan bahwa $L_{o}<L_{t}$ untuk kedua kelas sampel, ini berarti kedua kelas sampel berasal dari populasi yang terdistribusi normal. Selain data berasal dari sampel yang terdistribusi normal, harus diperhatikan juga apakah kedua sampel homogen atau tidak. Untuk itu dilakukan uji homogenitas seperti disajikan pada Tabel 4.

\begin{tabular}{llllll}
\multicolumn{4}{c}{ Tabel 4. Hasil Uji Homogenitas Hasil Tes Akhir } \\
\cline { 1 - 3 } Kelas & $\mathrm{N}$ & $\mathrm{s}^{2}$ & $\mathrm{~F}_{\mathrm{h}}$ & $\mathrm{F}_{\mathrm{t}}$ & Ket \\
\hline Eksperimen & 24 & 42,978 & 1,1 & 2,03 & Homogen \\
\cline { 1 - 3 } Kontrol & 23 & 45,676 & & &
\end{tabular}

Pada Tabel 4 nilai $\mathrm{F}_{\mathrm{t}}$ pada kelas eksperimen dan kelas kontrol dengan $\mathrm{dk}_{1} 22$ dan $\mathrm{dk}_{2}$ 23 adalah 2,03 pada taraf nyata 0,05 sedangkan $F_{h}$ adalah 1,1. Dari data dapat dilihat bahwa $\mathrm{F}_{\mathrm{h}}<\mathrm{F}_{\mathrm{t}}$ artinya kedua kelas sampel mempunyai variansi yang homogen.

Berdasarkan uji normalitas dan uji homogenitas data hasil belajar tes akhir didapatkan bahwa kedua kelas sampel terdistribusi normal dan mempunyai variansi yang homogen, sehingga menguji hipotesis digunakan uji kesamaan dua rata-rata (uji t) seperti yang tercantum dalam Tabel 5.

\begin{tabular}{lcccccc}
\multicolumn{6}{c}{ Tabel 5. Hasil Uji Kesamaan Dua Rata-Rata (Uji t) } \\
\cline { 1 - 5 } Kelas & $\mathrm{N}$ & $\bar{X}$ & $\mathrm{~S}$ & $\mathrm{~s}^{\mathbf{2}}$ & $\mathrm{t}$ & $\mathrm{t}$ tabel \\
& & & & & hitung & \\
\cline { 1 - 5 } Eksperimen & 24 & 84,75 & 6,55 & 42,978 & 2,04 & 1,67 \\
\cline { 1 - 3 } Kontrol & 23 & 80,69 & 6,76 & 45,676 & & \\
\hline
\end{tabular}

Pengujian ini didasarkan pada data hasil belajar kelas eksperimen dan kelas kontrol yang terdistribusi normal dan memiliki varians yang homogen. Setelah dilakukan perhitungan diperoleh nilai varians $\left(\mathrm{S}^{2}\right)$ pada kelas eksperimen adalah 42,978 dan kelas kontrol 45,676. Dari Tabel 5 dapat dilihat bahwa harga $t_{\text {hitung }}=2,04$. Dalam menguji hipotesis, harga thitung dibandingkan dengan $t_{\text {tabel }}$ pada tingkat kepercayaan $95 \%$ dengan taraf signifikansi $(\alpha=$ $0,05)$, derajat kebebasan $\mathrm{dk}=\mathrm{n}-1$ melalui tabel didapatkan nilai tabel adalah 1,67.

Nilai $t_{\text {tabel }}$ yang telah diperoleh kemudian dibandingkan dengan nilai thitung. Dari data yang didapatkan terlihat bahwa thitung $>t_{\text {tabel, }} 2,04>1,67$. Ini berarti thitung berada di luar daerah penerimaan $\mathrm{H}_{\mathrm{o}}$. Dengan adanya perbedaan nilai antara thitung dengan $t_{\text {tabel }}$ menunjukkan bahwa terdapat perbedaan yang berarti antara hasil belajar Fisika menggunakan bahan ajar Fisika dengan variasi bentuk tugas berbasis web dengan yang tidak menggunakan bahan ajar Fisika dengan variasi bentuk tugas berbasis web.

Kegiatan pembelajaran berkaitan dengan bagaimana meningkatkan rasa ingin tahu mahasiswa. Keingintahuan dapat ditumbuhkan atau dihilangkan sangat tergantung pada bagaimana pembelajaran dilakukan. Cara untuk mengembangkan rasa ingin tahu mahasiswa dapat dirancang melalui pengajaran yang berorientasi pada proses (Zakirman, Lufri, Khairani, \& Rahayu, 2020b). Untuk mengembangkan rasa ingin tahu mahaiswa dapat melalui kegiatan menyelesaikan soal-soal.

Dalam bahan ajar dengan variasi tugas berbasis web ini terdapat berbagai bentuk soal seperti yang ditunjukan gambar 1 . Bentuk soal diletakan dibagian penugasan. Bentuk soal ini terdiri dari bentuk soal benar-salah (true-false), bentuk soal menjodohkan (matching), 
bentuk soal melengkapi (embedded answer), bentuk soal pilihan ganda (multiple choice), dan bentuk soal essay. Selama proses pembelajaran mahasiswa diminta mengerjakan soalsoal tersebut. Semakin sering berlatih soal maka rasa ingin tahu mahasiswa juga semakin meningkat. Dengan demikian mahasiswa akan terlatih untuk belajar serta memiliki konsekuensi penting untuk apa mereka memperhatikan, bagaimana mereka memproses informasi, dan bagaimana mereka bereaksi terhadap kuliah (Eliyarti \& Rahayu, 2019a).

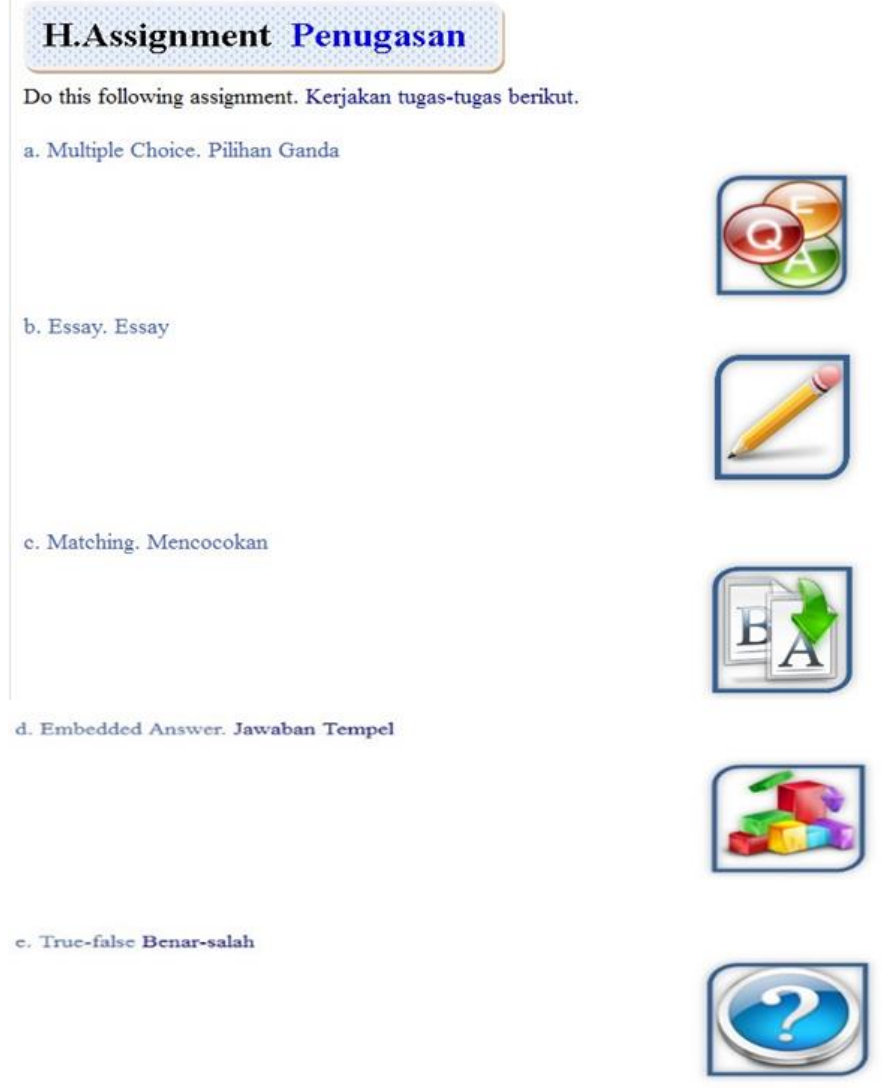

Gambar 1. Tampilan bahan ajar dengan variasi tugas berbasis web bagian penugasan

Adanya perbedaan hasil belajar yang berarti menunjukkan bahan ajar Fisika dengan variasi bentuk tugas berbasis web memberikan pengaruh terhadap hasil belajar mahasiswa. Selama pembelajaran terlihat mahasiswa terlibat aktif dan lebih termotivasi dalam menyelesaikan tugas yang diberikan. Dalam kegiatan pembelajaran membuat perubahan dan memvariasikan bentuk tugas mendorong mahasiswa untuk lebih kreatif (Gustina, Ananda, Kosasih, Zakirman, \& Ardimen, 2020). Dengan memberikan variasi ini diharapkan akan mengembangkan motivasi mahasiswa dalam pembelajaran.

Motivasi menjadi proses yang menjelaskan intensitas, arah dan ketekunan seseorang individu untuk mencapai tujuannya (Eliyarti \& Rahayu, 2019b). Dengan adanya motivasi akan meningkatkan pengoptimalan aktivitas berpikir sehingga dapat meningkatkan pemahaman konsep (Rahayu \& Festiyed, 2018). Selain itu, keterampilan berpikir penting untuk dilatihkan dalam pembelajaran Fisika. Keterampilan berpikir mampu membentuk kompetensi dan karakteristik mahasiswa (Rahayu, Eliyarti, \& Festiyed, 2019).

\section{Simpulan dan Saran}

Nilai rata-rata hasil belajar Fisika mahasiswa kelas eksperimen adalah 84,75 sedangkan kelas kontrol 80,69. Hal ini menunjukan hasil belajar Fisika mahasiswa kelas eksperimen lebih tinggi dari nilai rata-rata hasil belajar Fisika kelas kontrol. Selanjutnya berdasarkan hasil uji-t terhadap hasil belajar tersebut diperoleh bahwa thitung $>t_{\text {tabel, }}$ yaitu $2,04>1,67$. Ini berarti thitung berada di luar daerah penerimaan $\mathrm{H}_{\mathrm{o}}$. Dengan adanya perbedaan nilai antara $t_{\text {hitung }}$ dengan $t_{\text {tabel }}$ menunjukkan bahwa terdapat perbedaan yang 
berarti antara hasil belajar Fisika menggunakan bahan ajar Fisika dengan variasi bentuk tugas berbasis web dengan yang tidak menggunakan bahan ajar Fisika dengan variasi bentuk tugas berbasis web. Adanya perbedaan hasil belajar yang berarti menunjukkan bahan ajar Fisika dengan variasi bentuk tugas berbasis web memberikan pengaruh terhadap hasil belajar mahasiswa.

Salah satu tantangan dalam pembelajaran menggunakan bahan ajar berbasis web adalah ketersediaan fasilitas ICT serta tenaga listrik yang memadai. Untuk itu disarankan pada pelaksaan penelitian selanjutnya untuk mengoptimalkan fasilitas ICT di kampus agar mahasiswa tidak terkendala dalam pembelajaran online.

\section{Daftar Pustaka}

Bhakti, Y. B. (2017). Meningkatkan Hasil Belajar Fisika Menggunakan Metode Pemberian Fisika Menggunakan Metode Pemberian Tugas Terstruktur. Jurnal Pendidikan Fisika, $V(2), 138-147$.

Daryanto, D. (2014). Pengembangan Perangkat Pembelajaran. Yogyakarta: Gava Media.

Eliyarti, E., \& Rahayu, C. (2019a). Deskripsi Efektivitas Kegiatan Praktikum Dalam Perkuliahan Kimia Dasar Mahasiswa Teknik. Edu Sains : Jurnal Pendidikan Sains \& Matematika, 7(2), 51-60.

Eliyarti, E., \& Rahayu, C. (2019b). Tinjauan Motivasi Berprestasi Mahasiswa Teknik Dalam Perkuliahan Kimia Dasar. Jurnal Pendidikan Glasser, 3(2), 196-204.

Gusta, W., Christina, D., \& Zakirman, Z. (2020). Improved Student Collaboration Skills On English Learning Using Jigsaw Models. International Journal of Scientific \& Technology Research (IJSTR), 9(03), 1051-1056.

Gustina, G., Ananda, A., Kosasih, A., Zakirman, Z., \& Ardimen, A. (2020). Contribution Of Edmodo Smartphone Application To Support Assessment Activities In The Social Science Learning Process; Students Review. International Journal of Scientific \& Technology Research (IJSTR), 9(03), 774-777.

Hartanto, A. ., \& Purbo, O. . (2005). Teknologi ELearning Berbasis PHP dan MYSQL. Jakarta: Elek Media Komputindo.

Herayanti, L., Fuadunnazmi, M., \& Habibi, H. (2017). Pengembangan Media Pembelajaran Berbasis Moodle Pada Matakuliah Fisika Dasar. Cakrawala Pendidikan, XXXVI(2), 210 219.

Hidayatulah, A. H., Yushardi, Y., \& Wahyuni, S. (2013). Pengembangan Bahan Ajar Berbasis Web Interaktif Dengan Aplikasi E-Learning Moodle Pada Pokok Bahasan Besaran Dan Satuan di SMA. Jurnal Pendidikan Fisika, 4(2), 110-115.

Martono, S. M. (2017). Pengaruh Pemberian Tugas Berbasis Multimedia Terhadap Hasil Belajar Fisika Pada Mahasiswa. Jurnal Karkasa, 3(1), 1-4.

Prihatini, M. (2018). Penerapan Model Pembelajaran Pemberian Tugas Rumah Untuk Meningkatkan Hasil Belajar PKn Pada Siswa Kelas VIII-B SMP Negeri 3 Tapung. Jurnal Madania, 8(1), 53-66.

Purmadi, A., \& Surjono, H. D. (2016). Pengembangan Bahan Ajar Berbasis Web Berdasarkan Gaya Belajar Siswa Untuk Mata Pelajaran Fisika. Jurnal Inovasi Teknologi Pendidikan, 3(2), 151-165.

Putri, S. D., Ulhusna, M., Zakirman, Z., \& Gusta, W. (2020). Improvement of Student Science Literacy Skills Through Edmodo- Based Teaching Materials in Learning Science in Elementary School. International Journal of Scientific \& Technology Research (IJSTR), 9(03), 4649-4652.

Rahayu, C., \& Eliyarti, E. (2019). Implementation of Physics Learning Materials Based Generative Learning With Open-Ended Problem Approach To Stimulate Critical Thinking Skills. JIPF (Jurnal Ilmu Pendidikan Fisika), 4(2), 99. 
https://doi.org/10.26737/jipf.v4i2.1096

Rahayu, C., Eliyarti, E., \& Festiyed, F. (2019). Kepraktisan Perangkat Pembelajaran Berbasis Model Generative Learning dengan Pendekatan Open-ended Problem. Berkala Ilmiah Pendidikan Fisika, 7(3), 164-176. https://doi.org/10.20527/bipf.v7i3.6139

Rahayu, C., \& Festiyed. (2018). Validitas Perangkat Pembelajaran Fisika SMA Berbasis Model Pembeljaran Generatif Dengan Pendekatan Open-Ended Problem Untuk Menstimulus Keterampilan Berpikir Kritis Peserta Didik. Jurnal Pendidikan Fisika, 7(1), $1-6$.

Setiawan, A., \& B, I. W. (2017). Desain Bahan Ajar Yang Berorientasi Pada Model Pembelajaran Student Team Achievement Division Untuk Capaian Pembelajaran Pada Ranah Pemahaman Siswa Pada Mata pelajaran IPS Kelas VII SMP Negeri 1 Plered Kabupaten Cirebon. Jurnal Edunomic, 5(01), 17-32.

Sudjana, N. (2011). Dasar-dasar Proses Belajar Mengajar. Bandung: Sinar Baru Algensindo. Supardi, U. ., Leonard, L., Suhendri, H., \& Rismurdiyati, R. (2018). Pengaruh Media Pembelajaran Dan Minat Belajar Terhadap Hasil Belajar Fisika. Jurnal Formatif, 2(1), 71-81.

Tambunan, H. (2013). Pengembangan Pembelajaran Berbasis Website Dalam Matakuliah Pengaturan Mesin Listrik. Cakrawala Pendidikan, XXXII(1), 64-76.

Uzer, U. (2008). Menjadi Guru Profesional. Bandung: PT. Remaja Rosdakarya.

Yulizon, Y. (2017). Penerapan Metode Pemberian Tugas Untuk Meningkatkan Kemampuan Guru Dalam Memanfaatkan Lingkungan Sekolah Sebagai Sumber Belajar SDN 001 Kunto Darussalam. Jurnal Pendidikan Dan Pengajaran Program Studi Pendidikan Guru Sekolah Dasar FKIP Universitas Riau, 1(14), 153-160.

Zakirman, Z. (2019). Peningkatan Minat Baca Siswa Melalui Penerapan Model Pembelajaran Play-Think-Pair-Share di SDN 19 Nan Sabaris. Shaut Al-Maktabah: Jurnal Perpustakaan, Arsip Dan Dokumentasi, 11(1), 41-51. https://doi.org/10.15548/shaut.v11i1.162

Zakirman, Z., Lufri, L., \& Khairani, K. (2018). Factors Influencing the Use of Lecture Methods in Learning Activities: Teacher Perspective. Advances in Social Science, Education and Humanities Research, 178(ICoIE 2018), 4-6.

Zakirman, Z., Lufri, L., Khairani, K., \& Rahayu, C. (2020a). Implementation of The PlayThink-Pair-Share (PTPS) Learning Model for Elementary School Students to Master Part of Top Skill 2020. International Journal of Scientific \& Technology Research (IJSTR), 9(03), 4643-4648.

Zakirman, Z., Lufri, L., Khairani, K., \& Rahayu, C. (2020b). The effect of using play-thinkpair-share ( PTPS ) model to improve student learning outcomes in magnet topic for elementary school. IOP Conference Series: Journal of Physics, 1481, 0-11. https://doi.org/10.1088/1742-6596/1481/1/012078

Zakirman, Z., \& Rahayu, C. (2018). Popularitas WhatsApp sebagai Media Komunikasi dan Berbagi Informasi Akademik Mahasiswa. Shaut Al-Maktabah: Jurnal Perpustakaan, Arsip Dan Dokumentasi, 10(1), 27-38. 